\title{
Seasonal changes in density, biomass, and diversity of estuarine fishes in tidal mangrove creeks of the lower Caeté Estuary (northern Brazilian coast, east Amazon)
}

\author{
Mário Barletta $^{1,2, *}$, Audrey Barletta-Bergan², Ulrich Saint-Paul' ${ }^{2}$, Gerd Hubold ${ }^{3}$ \\ ${ }^{1}$ Departamento de Oceanografia, UFPE, Cidade Universitária, 50740-550, Recife, Pernambuco, Brazil \\ ${ }^{2}$ Center for Tropical Marine Ecology, Fahrenheitstrasse 6, 28359 Bremen, Germany \\ ${ }^{3}$ Bundesforschungsanstalt für Fischerei, Palmaille 9, 22767 Hamburg, Germany
}

\begin{abstract}
The present study investigated the assemblage of fish species in an intertidal mangrove forest during high tide in a macrotide region. We describe the seasonal changes in the fish assemblage composition in relation to biomass, density, and species number in tidal creeks of the Furo do Meio, Caeté Estuary, Brazil. A total of 29107 individuals of 49 species in 26 families were caught using a block net. Their total weight was $526 \mathrm{~kg}$ (total density 0.11 ind. $\mathrm{m}^{-2}$ and total biomass $2.1 \mathrm{~g} \mathrm{~m}^{-2}$ ). Analysis of the catch data showed that the number of species varied significantly between creeks, and that total fish biomass differed significantly between seasons. The densities and biomass of the 2 most important species, Cathorops pleurops and Colomesus psittacus, were significantly different between seasons. The densities and biomass of C. pleurops, Pterengraulis atherinoides, Pseudauchnipterus nodosus, and Stellifer naso showed significant temporal differences. Significant differences between creeks were observed in the density and biomass of Anchovia clupeoides and Rhinosardinia amazonica. The abundance-biomass comparison $(\mathrm{ABC})$ plots for the fish fauna in the creeks of the Furo do Meio showed that the dominant species increased in number and weight at the beginning of the rainy season. As a result of increased rainfall in March and April, salinity declined to values between 6 and $8 \mathrm{psu}$. At that time, the dominant species made up more than $60 \%$ of the total biomass and density and Hill's index of diversity (N1) declined, whereas the number of species (N0) and evenness (E2) did not change. After April, rainfall decreased, and density and biomass returned to levels similar to those before the rainy season. The number of species and the density and biomass in the mangrove tidal creeks are compared with published data for other tropical and subtropical estuaries. Migration trends were inferred from the results of the seasonal fluctuations of density and biomass of the most important species in the Furo do Meio, and are compared with data from other studies in the main channel of the Caeté Estuary.
\end{abstract}

KEY WORDS: Estuarine fishes · Caeté Estuary · Eastern Amazon · Mangrove tidal creeks · Macrotide region · Fish assemblages

\section{INTRODUCTION}

The export of plant detritus and faunal biomass to support offshore consumers is an important function of mangrove swamps, which is a strong argument for their conservation. Mangroves provide refuges for adult and larval stages of fishes and crustaceans, many of which are commercially important (Blaber \& Blaber 1980, Griffin 1985, Lenaton \& Potter 1987, Robertson \& Duke 1990). However, mangrove forests are unstable habitats in which salinity and dissolved oxygen fluctuate greatly (Kjerfvue 1990, Barletta et al. 2000, Blaber 2000). Many intertidal fishes are able to withstand these environmental changes (Barletta et al. 
2000). This ecosystem is used by many marine species as a nursery ground. Only a few fish groups are resident and spawn in the mangrove forest (Blaber 2000). Some species have a very specific habitat preference, and care for their eggs (Gibson 1996). Other species inhabit crab burrows or mudflat pools during low tide (Barletta et al. 2000).

During high tide, the physical and chemical conditions of the water in the mangrove creeks almost mirror those of the main channel, and tend to be uniform during flood tide. At that time, a large number of zooand ichthyoplankton, crustaceans and fishes inhabit the creeks in the mangrove forest (Robertson \& Blaber 1992). Most fish species using the mangrove forest during high tide move into tidal channels or directly into the bay of the estuary at ebb tide (Blaber et al. 1989, Robertson \& Blaber 1992).

There is a wide range in the degree of mixing of fresh and salt water in tropical estuaries, from completely flushed systems during the rainy season, where salt water is found only outside the estuary, to mangrove creeks in the dry season (Kjerfvue 1990, Robertson \& Blaber 1992). For this reason, the fish species in any tropical estuary are exposed to high ranges of salinity (LoweMcConnell 1987). Many fishes are well adapted to these salinity fluctuations and are resident in the mangrove forest (Barletta et al. 2000); others live in the system only during their early life, and later move back to adjacent habitats where salinity is more stable (Barletta-Bergan et al. 2002).

Along the northern Brazilian coast, the creeks of mangrove forests are flooded during high tide due to the influence of macrotides (4 to $5 \mathrm{~m}$ ). During this time, the fishermen of this region block the outlets of small mangrove tidal creeks with net barriers ('tapagem'). Fishes are collected in the small pools that form $6 \mathrm{~h}$ after the creek stops flowing, during stagnation at low tide (Barletta et al. 1998).

Studies utilizing block nets in mangrove tidal creeks have reported fish species composition, abundance, and biomass in south Florida (Thayer et al. 1987), and species diversity and biomass in the Solomon Islands and in the Embley Estuary and Moreton Bay, Australia (Blaber et al. 1989, Blaber \& Milton 1990, Morton 1990). Along the Brazilian coast, similar studies have been conducted in mangrove tidal creeks in the Tibiri Estuary, state of Maranhão (Batista \& Rêgo 1996) and in the mangrove forest during low tide in the Caeté Estuary (Barletta et al. 2000). For the Tibiri Estuary, Batista \& Rêgo (1996) described the fish assemblage in relation to rainfall. Barletta et al. (2000) reported on fish composition, density and biomass in the mangrove forest, and described 3 different ecological strategies developed by some intertidal fish species to survive in the mangrove forest during low tide. However, little is known about the composition, density and biomass of intertidal fish species, which make use of the resources of intertidal areas only when these are submerged.

The objective of this study was, therefore, to identify the seasonal changes in the composition of fish species in relation to density, biomass and species number in 3 tidal creeks in the inner part of the Furo do Meio in the Caeté Estuary. Furthermore, this study evaluates the null hypothesis that the number of fish species, total density and total biomass are equal in different creeks of the Furo do Meio and during different seasons.

\section{MATERIALS AND METHODS}

Study area. The Furo do Meio is a tidal channel located on the left side of the Caeté Estuary in NE Pará, Brazil (Fig. 1). The Caeté River is in the northern part of the East Brazilian Basin. The climate is hot and humid (mean air temperature $25.7^{\circ} \mathrm{C}$ ), with dry periods from August to December and a rainy season from January to

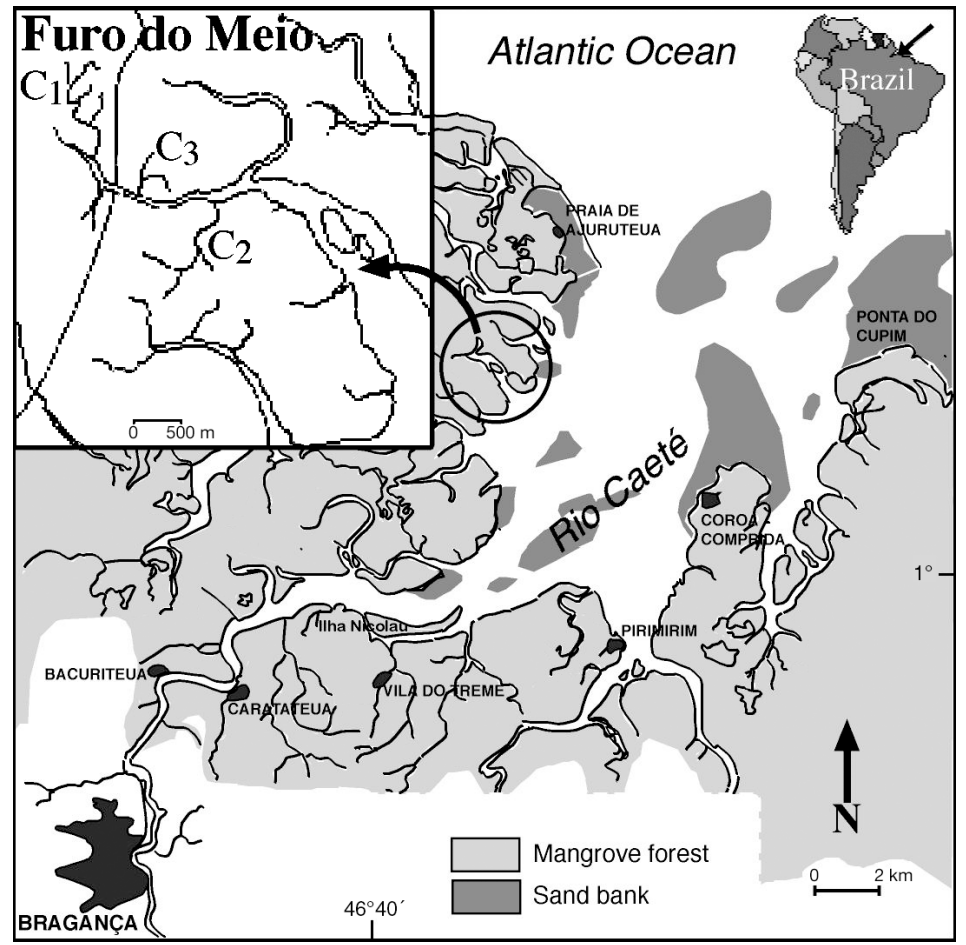

Fig. 1. Caeté Estuary, showing the 3 creeks in the Furo do Meio $(\mathrm{C} 1, \mathrm{C} 2$, and C3) where samples were taken with block nets (net barriers known locally as 'tapagem') 
July. Annual precipitation exceeds $2545 \mathrm{~mm}$. During the rainy season, freshwater runoff from the Caeté and Urumajó Rivers increases, and salinity decreases to 6 psu. Salinity is higher during the dry season (>35 psu).

In this area, the coastal plain is a macrotidal (4 to $5 \mathrm{~m}$ ) depositional system characterized by sand-mud and mud sediments. Many tidal creeks drain the mangrove forest in this region, and it is flooded twice daily at high tide. At low tide these creeks have no influx of tidal water.

Sampling methods. Samples were taken monthly between October 1996 and October 1997 from 3 tidal creeks in the Furo do Meio (Fig. 1: C1, C2, and C3). Water temperature $\left({ }^{\circ} \mathrm{C}\right)$, dissolved oxygen $\left(\mathrm{mg} \mathrm{l}^{-1}\right)$ (Wissenschaftlich Technische Werkstätten, WTW OXI 325), and salinity (psu) (WTW LF 197) were recorded at the water surface. The width and length between meanders were measured for each creek at high tide. With this information, the flooded area was calculated (Creek 1: $6481 \mathrm{~m}^{2}$; Creek 2: $9351 \mathrm{~m}^{2}$; Creek 3: $1856 \mathrm{~m}^{2}$ ). Sampling was carried out during the last quarter moon (neap tide) each month. The creeks were sampled by blocking the creek entrances with a $1 \mathrm{~cm}$-mesh net $(50 \times 5 \mathrm{~m})$ (Barletta et al. 1998). All fishes were counted, wet-weighed ( $\mathrm{g})$, and measured (cm). Density is expressed as ind. $\mathrm{m}^{-2}$ and biomass as $\mathrm{g} \mathrm{m}^{-2}$.

Species classification. The fish species were classified according to the ecological guilds described by Mathieson et al. (2000), who proposed 6 ecological guilds: truly estuarine resident species, marine adventitious visitors, diadromous (catadromous/anadromous) migrants, marine and freshwater juvenile migrants (nursery) and freshwater adventitious visitors.

Statistical analysis. Analyses of variance were performed to determine whether significant differences in

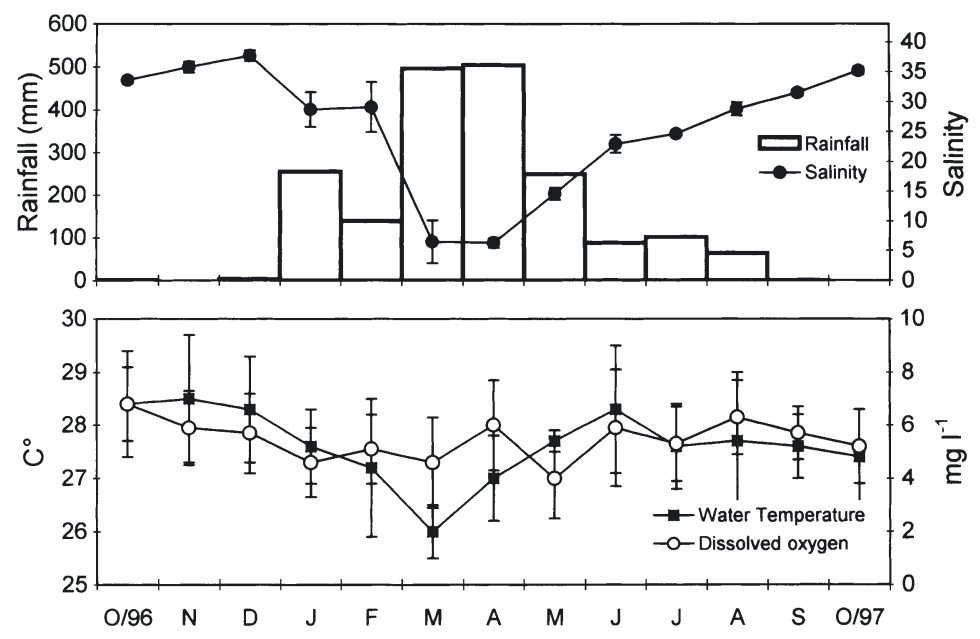

Fig. 2. Total rainfall $(\mathrm{mm})$ and mean $( \pm \mathrm{SD})$ values of water salinity, temperature $\left({ }^{\circ} \mathrm{C}\right)$ and dissolved oxygen $\left(\mathrm{mg} \mathrm{l}^{-1}\right)$ in the Furo do Meio, Caeté Estuary, Brazil fish density, biomass, and number of species occur among creeks and over time: 2-way ANOVAs were used to test for differences in the fish community parameters among creeks (C1, C2, and C3) and between seasons (dry and rainy). Data were $\log (x+1)$ transformed to increase the normality of distribution. Cochran's test was used to check the homogeneity of variances. When variances were deemed heterogeneous at $\mathrm{p}<0.05$ but not lower than $\mathrm{p}<0.01$, the analysis of variance used the lower probability level $(p<0.01)$. When homogeneity of variances was lower than $\mathrm{p}<0.01$, a non-parametric Kruskal-Wallis test with a $5 \%$ level of significance was used. When the assumptions of parametric statistics could not be met, a non-parametric Kruskal-Wallis test with a 5\% level of significance was used (Zar 1996). Tukey's multiple comparisons test $(\mathrm{p}<0.05)$ was used whenever significant differences were detected (Day \& Quinn 1989).

A similarity matrix using Euclidean-distance was computed for the $\mathrm{Q}$ analysis (coefficient similarity matrix among samples) (Romesburg 1984), where the abiotic factors (salinity, temperature, dissolved oxygen) were considered attributes (Clarke \& Warwick 1994). To avoid the high value units, the environmental data were $\log$-transformed $[(\log (x+1)]$ so that their distributions approached normality.

In the $\mathrm{R}$ analysis (coefficient similarity matrix among species), the species matrix (densities) was computed using $\log (x+1)$-transformed data also. Prior to analysis, the original data matrix was reduced to avoid the effect of rare species on the analysis (Gauch 1982). Species occurring in $<3 \%$ of the samples within the habitat were excluded. A similarity matrix using the Bray-Curtisn index was computed using PRIMER (Plymouth routines in multivariate ecological analysis: Clarke \& Warwick 1994). From the similarity matrix of samples by month, species cluster dendrograms were constructed using hierarchical group-average linking.

The abundance and biomass comparison (ABC) method was used to determine levels of 'disturbance' of the estuarine fish fauna during seasonal habitat variations (Clarke \& Warwick 1994). In addition, Hill's index of diversity (N1) and evenness index (E2) were calculated for each month, following Ludwig \& Reynolds (1988).

\section{RESULTS}

\section{Environmental variables}

Water salinity and temperature showed seasonal tendencies. At the end of December the rainy season began, and salinity decreased from 35 to $28 \mathrm{psu}$ (Fig. 2). Between March and May, the lowest sal- 
inity values (6 to $12 \mathrm{psu}$ ) were recorded. Subsequently, rainfall decreased and salinity increased once more. Mean $( \pm \mathrm{SD})$ dissolved oxygen $\left(\mathrm{mg} \mathrm{l}^{-1}\right)$ levels are also shown in Fig. 2.

Cluster analysis of the abiotic data (Fig. 3) differentiated 3 main groups. The first group comprised all samples from the dry season (>28 psu) plus those from the beginning of the rainy season (January and February). The second group contained all samples from the end of the rainy season (June and July). Therefore, the months January-February and June-July were considered as periods of transition between the dry and rainy seasons (20 to $28 \mathrm{psu}$ ). The third group comprised all the samples from the rainy season $(<20 \mathrm{psu})$.

\section{Composition of fish fauna}

Thirty-nine samples were taken from the mangrove creeks located in the inner part of the Furo do Meio. A total of 29107 individuals weighing $526 \mathrm{~kg}$ (mean density $=0.11$ ind. $\mathrm{m}^{-2}$; mean biomass $=2.06 \mathrm{~g} \mathrm{~m}^{-2}$ ) of 49 species in 26 families were captured with block nets (Table 1). Cathorops pleurops, Colomesus psittacus, and Anchovia clupeoides were the most important species, both in number ( $70 \%$ ) and weight ( $74 \%)$, of all catches. Mean lengths and ranges varied among species (Table 1). Trichiurus lepturus had the greatest mean length $(620 \mathrm{~mm})$, and Cyclichthys spinosus the smallest (11 mm: Table 1).

\section{Seasonal variations in density, biomass and number of species}

The data for the variables number of species, total density, total biomass, biomass of the main species, density, and biomass for the species Colomesus psittacus, Anchovia clupeoides, Pterengraulis atherinoides, Genyatremus luteus and Stellifer naso (density and biomass) and for Cathorops pleurops (biomass) were successfully transformed to fit the requirements of the analysis of variance (Underwood 1981). When transformations were unsuccessful, the Kruskal-Wallis test was used to compare densities and biomass for the species Centengraulis edentulus, Pseudauchnipterus nodosus, Rhinosardinia amazonica (density and biomass) and the main species and Cathorops pleurops (density).

The number of species did not differ significantly between seasons, but there were significant differences among creeks (Fig. 4, Table 2). Total fish densities did not differ significantly among creeks and between seasons; however, total fish biomass differed significantly between seasons (Fig. 4; Table 2). For the 2 most important species (Cathorops pleurops and

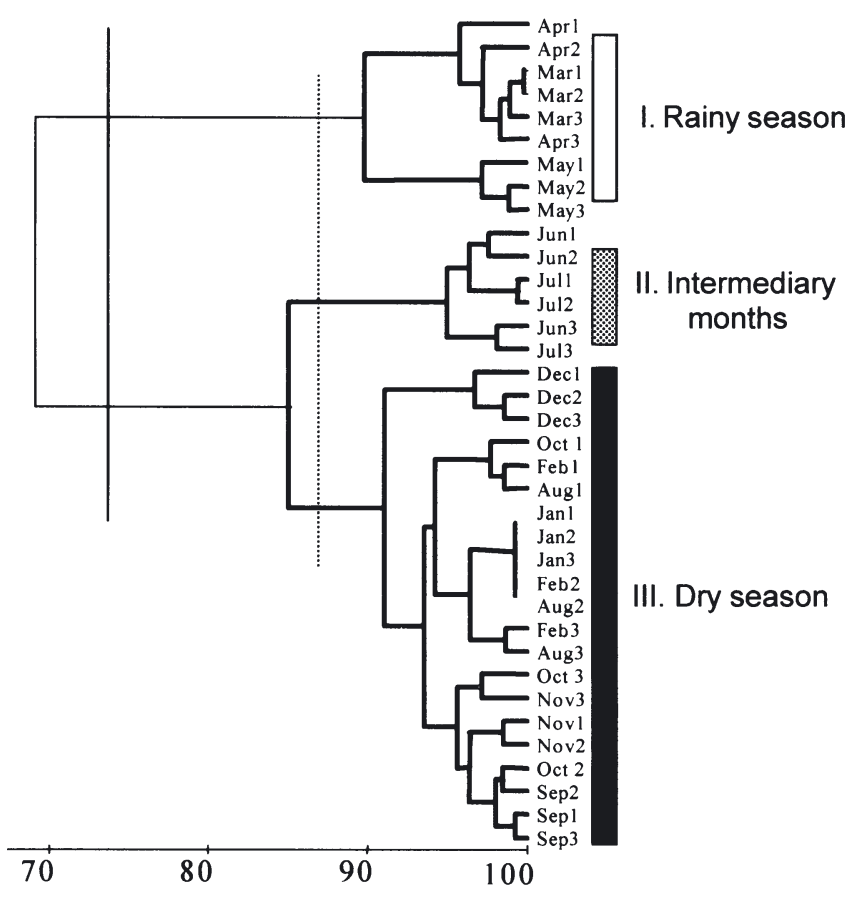

EUCLIDEAN DISTANCE

Fig. 3. Cluster dendrogram of abiotic data (salinity, temperature and dissolved oxygen) of 39 samples. Labels (month, creek) correspond to month and creek of sample collection. Samples were clustered using Euclidean index based on $\log (x+1)$-transformed data

\section{Dry season $\quad \square$ Rainy season}

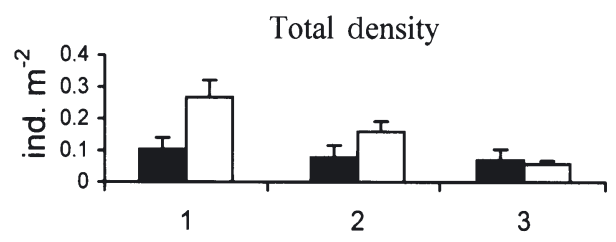

Total biomass
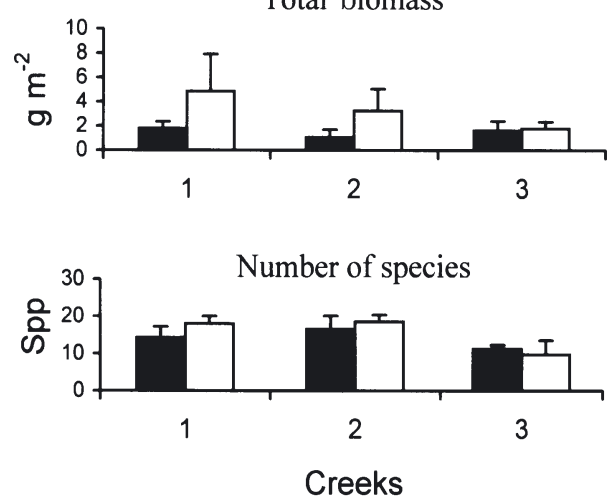

Fig. 4. Mean (+SD) range in total density, total biomass and number of species as a function of creek and season 
Table 1. Density, biomass, mean length and length range of fish species in mangrove creeks of Furo do Meio collected by block net (tapagem)

\begin{tabular}{|c|c|c|c|c|c|c|c|c|c|c|c|c|c|}
\hline \multirow[t]{3}{*}{ Species } & \multicolumn{2}{|c|}{ Density $(\bar{x})$} & \multicolumn{2}{|c|}{ Biomass $(\bar{x})$} & \multicolumn{3}{|c|}{ Density (\%) } & \multirow{2}{*}{\multicolumn{3}{|c|}{ Biomass (\%) }} & \multirow{3}{*}{$\begin{array}{c}\text { Fre- } \\
\text { quency } \\
(\%)\end{array}$} & \multirow{3}{*}{$\begin{array}{c}\text { Mean } \\
\text { length } \\
(\mathrm{mm})\end{array}$} & \multirow{3}{*}{$\begin{array}{c}\text { Length } \\
\text { range } \\
\text { (mm) }\end{array}$} \\
\hline & \multirow{2}{*}{\multicolumn{2}{|c|}{$\begin{array}{l}\text { ind. } \mathrm{m}^{-2} \quad \% \\
\left(\times 10^{4}\right)\end{array}$}} & \multirow{2}{*}{$\begin{array}{l}\mathrm{g} \mathrm{m}^{-2} \\
\left(\times 10^{4}\right)\end{array}$} & \multirow{2}{*}{$\%$} & & Creek & - & & & & & & \\
\hline & & & & & 1 & 2 & 3 & 1 & 2 & 3 & & & \\
\hline Cathorops pleurops & 504.16 & 46.7 & 8290.15 & 40.3 & 56.7 & 44.8 & 17.7 & 48.0 & 43.3 & 17.4 & 90 & 93 & $20-270$ \\
\hline Colomesus psittacus & 149.88 & 13.9 & 5573.57 & 27.1 & 12.8 & 12.8 & 20.4 & 29.5 & 22.8 & 28.6 & 97 & 68 & $20-270$ \\
\hline Anchovia clupeiodes & 105.78 & 9.8 & 1417.48 & 6.9 & 12.1 & 10.1 & 1.3 & 8.0 & 9.0 & 0.7 & 82 & 92 & $50-150$ \\
\hline Cetengraulis edentulus & 55.45 & 5.1 & 796.49 & 3.9 & 0.7 & 4.2 & 22.8 & 0.5 & 2.3 & 14.2 & 62 & 140 & $60-140$ \\
\hline Pterengraulis atherinoides & 54.79 & 5.1 & 727.93 & 3.5 & 4.8 & 5.3 & 5.5 & 3.9 & 3.7 & 2.4 & 87 & 99 & $60-180$ \\
\hline Anableps anableps & 31.66 & 2.9 & 909.76 & 4.4 & 0.1 & 2.2 & 14.3 & 0.9 & 2.2 & 16.3 & 72 & 123 & $40-220$ \\
\hline Genyatremus luteus & 24.21 & 2.2 & 357.69 & 1.7 & 2.0 & 3.3 & 0.4 & 1.8 & 2.5 & 0.4 & 67 & 62 & $30-190$ \\
\hline Stellifer naso & 24.02 & 2.2 & 337.96 & 1.6 & 1.7 & 3.5 & 0.6 & 1.3 & 2.9 & 0.3 & 62 & 73 & $50-140$ \\
\hline Pseudauchnipterus nodosus & S 21.91 & 2 & 195.79 & 1.0 & 2.8 & 1.8 & & 1.4 & 0.9 & & 18 & 70 & $40-160$ \\
\hline Rhinosardinia amazonica & 21.74 & 2 & 178.84 & 0.9 & 0.7 & 4.4 & 0.5 & 0.3 & 2.0 & 0.2 & 54 & 80 & $60-120$ \\
\hline Arius herzbergii & 18.61 & 1.7 & 343.57 & 1.7 & 0.7 & 1.7 & 5.2 & 0.5 & 2.4 & 3.1 & 67 & 40 & $40-180$ \\
\hline Mugil sp. 1 & 13.26 & 1.2 & 180.36 & 0.9 & 1.2 & 0.3 & 3.7 & 0.3 & 0.4 & 3.0 & 59 & 50 & $50-170$ \\
\hline Cynoscion acoupa & 10 & 0.9 & 118.69 & 0.6 & 1.0 & 0.8 & 1.2 & 0.6 & 0.6 & 0.5 & 67 & 40 & $40-170$ \\
\hline Chaetodipterus faber & 7.63 & 0.7 & 77.75 & 0.4 & 0.6 & 1.1 & & 0.4 & 0.5 & & 51 & 42 & $10-80$ \\
\hline Stellifer stellifer & 6 & 0.6 & 137.65 & 0.7 & 0.7 & 0.6 & & 0.8 & 0.8 & & 13 & 89 & $60-240$ \\
\hline Micropogonias furnieri & 5.63 & 0.5 & 53.77 & 0.3 & 0.3 & 0.8 & 0.5 & 0.2 & 0.5 & 0.2 & 46 & 72 & $50-150$ \\
\hline Oligoplites saurus & 5.21 & 0.5 & 77.81 & 0.4 & 0.3 & 0.5 & 0.9 & 0.3 & 0.4 & 0.6 & 67 & 94 & $40-170$ \\
\hline Selene vomer & 3.42 & 0.3 & 34.85 & 0.2 & 0.2 & 0.6 & 0.2 & 0.2 & 0.2 & 0.1 & 31 & 50 & $10-150$ \\
\hline Diapterus rhombeus & 2.42 & 0.2 & 36.33 & 0.2 & & 0.1 & 0.7 & & 0.1 & 0.4 & 26 & 62 & $40-100$ \\
\hline Citharichthys arenaceus & 2.41 & 0.2 & 11.83 & 0.1 & $<0.1$ & 0.3 & 0.8 & $<0.1$ & 0.1 & 0.1 & 33 & 54 & $40-90$ \\
\hline Gobionellus oceanicus & 1.81 & 0.2 & 35.16 & 0.2 & $<0.1$ & $<0.1$ & 1.1 & $<0.1$ & $<0.1$ & 0.8 & 18 & 127 & $110-140$ \\
\hline Achirus lineatus & 1.55 & 0.1 & 63.51 & 0.3 & $<0.1$ & 0.1 & 0.6 & $<0.1$ & 0.2 & 1.1 & 38 & 80 & $30-190$ \\
\hline Centropomus paralellus & 1.23 & 0.1 & 17.57 & 0.1 & $<0.1$ & 0.1 & 0.4 & $<0.1$ & 0.1 & 0.1 & 23 & 85 & $60-150$ \\
\hline Mugil sp. 2 & 1.14 & 0.1 & 14.78 & 0.1 & $<0.1$ & 0.2 & 0.3 & $<0.1$ & 0.1 & 0.1 & 8 & 86 & $70-110$ \\
\hline Batrachoides surinamensis & 0.76 & 0.1 & 348.67 & 1.7 & $<0.1$ & $<0.1$ & 0.4 & $<0.1$ & 0.8 & 7.0 & 23 & 218 & $10-330$ \\
\hline Stellifer rastrifer & 0.64 & 0.1 & 10 & $<0.1$ & 0.1 & $<0.1$ & & 0.1 & 0.1 & & 18 & 86 & $70-100$ \\
\hline Lycengraulis grossidens & 0.62 & 0.1 & 12.12 & 0.1 & $<0.1$ & 0.1 & & $<0.1$ & 0.1 & & 23 & 114 & $70-140$ \\
\hline Lutjanus jocu & 0.51 & $<0.1$ & 8.83 & $<0.1$ & $<0.1$ & $<0.1$ & 0.2 & $<0.1$ & 0.1 & 0.1 & 13 & 81 & $60-100$ \\
\hline Cynoscion leiarchus & 0.47 & $<0.1$ & 8.22 & $<0.1$ & 0.1 & $<0.1$ & & 0.1 & $<0.1$ & & 23 & 94 & $50-160$ \\
\hline Bairdiella ronchus & 0.42 & $<0.1$ & 5.97 & $<0.1$ & $<0.1$ & 0.1 & & $<0.1$ & 0.1 & & 13 & 78 & $60-110$ \\
\hline Caranx hippos & 0.31 & $<0.1$ & 9.29 & $<0.1$ & $<0.1$ & $<0.1$ & & 0.1 & $<0.1$ & & 10 & 73 & $40-130$ \\
\hline Strongylura timocu & 0.28 & $<0.1$ & 26.51 & 0.1 & $<0.1$ & $<0.1$ & & 0.1 & 0.2 & & 15 & 383 & $340-450$ \\
\hline Chloroscombrus chrysurus & 0.23 & $<0.1$ & 0.33 & $<0.1$ & $<0.1$ & $<0.1$ & 0.1 & $<0.1$ & $<0.1$ & $<0.1$ & 10 & 37 & $30-40$ \\
\hline Tarpon atlanticus & 0.20 & $<0.1$ & 38.83 & 0.2 & $<0.1$ & & & 0.4 & & & 8 & 167 & $9-30$ \\
\hline Aspredinichthys tibicen & 0.16 & $<0.1$ & 1.39 & $<0.1$ & $<0.1$ & $<0.1$ & & $<0.1$ & $<0.1$ & & 8 & 153 & $130-190$ \\
\hline Sphoeroides testudineus & 0.15 & $<0.1$ & 10.54 & 0.1 & $<0.1$ & $<0.1$ & & 0.1 & $<0.1$ & & 8 & 110 & $120-100$ \\
\hline Epinephelus itayara & 0.14 & $<0.1$ & 100.38 & 0.5 & & & 0.1 & & & 2.4 & 3 & 550 & 550 \\
\hline Trichiurus lepturus & 0.14 & $<0.1$ & 25.47 & 0.1 & & $<0.1$ & & & 0.4 & & 8 & 620 & $540-700$ \\
\hline Scomberomorus maculatus & 0.09 & $<0.1$ & 2.59 & $<0.1$ & $<0.1$ & $<0.1$ & & $<0.1$ & $<0.1$ & & 5 & 130 & $120-140$ \\
\hline Arius passany & 0.08 & $<0.1$ & 0.92 & $<0.1$ & & $<0.1$ & & & $<0.1$ & & 5 & 110 & 110 \\
\hline Caranx crysos & 0.08 & $<0.1$ & 0.19 & $<0.1$ & $<0.1$ & & & $<0.1$ & & & 3 & 40 & 40 \\
\hline Polydactylus virginicus & 0.07 & $<0.1$ & 0.89 & $<0.1$ & $<0.1$ & $<0.1$ & & $<0.1$ & $<0.1$ & & 5 & 80 & 80 \\
\hline Chilomycterus spinosus & 0.04 & $<0.1$ & 0.08 & $<0.1$ & $<0.1$ & & & $<0.1$ & & & 3 & 11 & $100-200$ \\
\hline Anchoa spinifer & 0.04 & $<0.1$ & 0.02 & $<0.1$ & $<0.1$ & & & $<0.1$ & & & 3 & 90 & $60-140$ \\
\hline Oligoplites saliens & 0.04 & $<0.1$ & 0.23 & $<0.1$ & $<0.1$ & & & $<0.1$ & & & 3 & 63 & $50-120$ \\
\hline Cynoscion microlepidotus & 0.03 & $<0.1$ & 1.63 & $<0.1$ & & $<0.1$ & & & $<0.1$ & & 3 & 93 & $60-150$ \\
\hline Caranx bartholomei & 0.03 & $<0.1$ & 0.05 & $<0.1$ & & $<0.1$ & & & $<0.1$ & & 3 & 40 & 40 \\
\hline Caranx latus & 0.03 & $<0.1$ & 0.26 & $<0.1$ & & $<0.1$ & & & $<0.1$ & & 3 & 100 & 100 \\
\hline Cynoscion steindachneri & 0.03 & $<0.1$ & 4.18 & $<0.1$ & & $<0.1$ & & & 0.1 & & 3 & 200 & 200 \\
\hline Total $\left(\times 10^{4}\right)$ & $10^{7}$ & 79 & 205 & 594 & 1588 & 1182 & 466 & 28621 & 20682 & 12479 & & & \\
\hline No. of species & 4 & 19 & & & 41 & 43 & 25 & & & & & & \\
\hline No. of samples & & 39 & & & 13 & 13 & 13 & & & & & & \\
\hline
\end{tabular}




\section{a. Density}
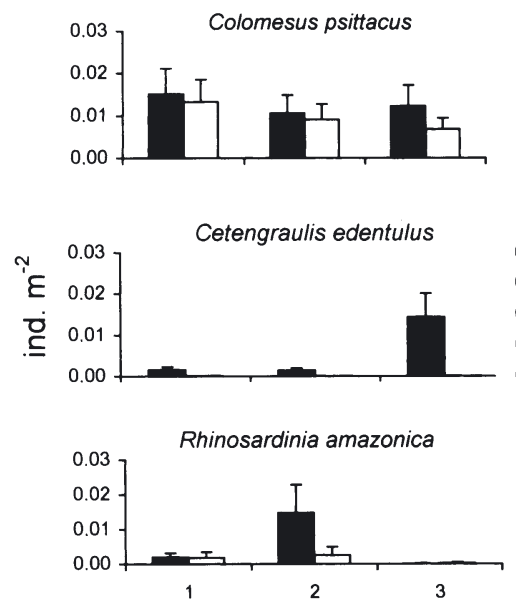

\section{b. Biomass}

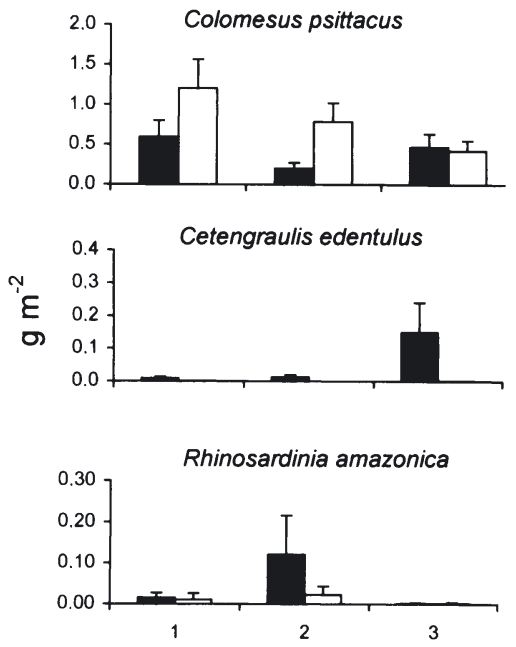

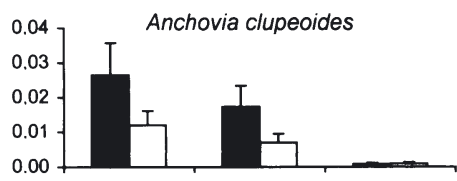
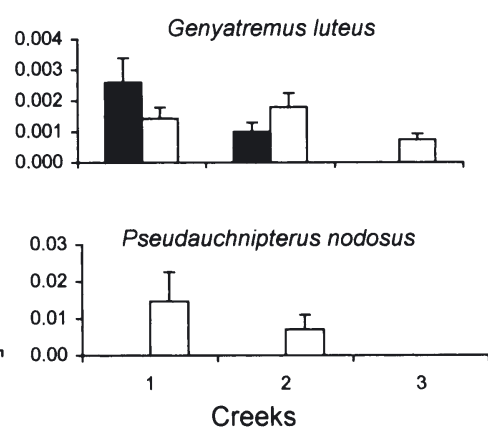
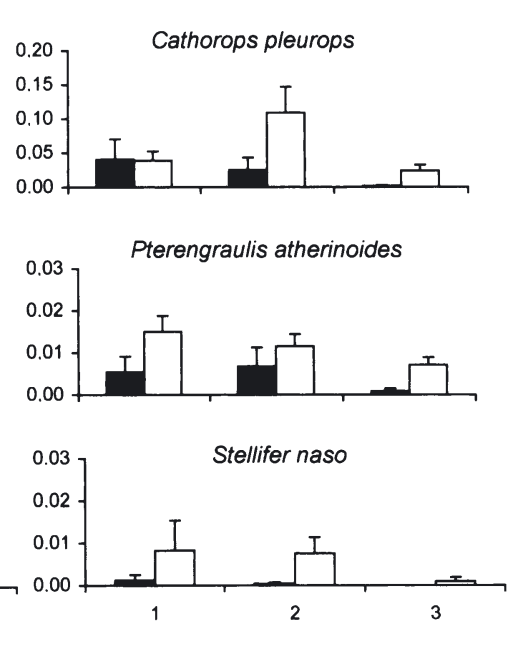

Dry season $\square$ Rainy season 
the Furo do Meio only at salinities between 6 and $12 \mathrm{psu}$. This species was considered a fresh-brackishwater adventitious visitor.

Fig. 7 shows the diversity index and $\mathrm{ABC}$ plots for the fish fauna in the creeks of the Furo do Meio. The density and biomass curves show that at the beginning of the rainy season the dominant species increased in number and weight. Between March and April the rainfall increased and salinity decreased from 6 to $8 \mathrm{psu}$. At this time the dominant species represented more than $60 \%$ of the total density and biomass. Therefore a reduction in the diversity index (N1) was recorded, whereas the number of species (N0) and evenness (E2) showed no changes (Fig. 7a). After April, rainfall decreased and the density and biomass curves showed trends similar to those in the period before the rainy season.

\section{DISCUSSION AND CONCLUSIONS}

\section{Intertidal fishes}

Fishes that utilize the intertidal mangrove areas as a habitat do so in 2 different ways: the first group remains in the intertidal area at low tide (Barletta et al. 2000), the second group avoids the intertidal area during low tide and makes use of this habitat only when it is submerged.

Of 49 fish species that make use of the intertidal mangrove forest during flood-tides, Cathorops pleurops, Colomesus psittacus and Anchovia clupeoides were the most important, independent of season. C. pleurops, Pterengraulis atherinoides, Pseudauchnipterus nodosus and Stellifer naso showed significant differences in density and biomass during the year, resulting in rejection of the null hypothesis. On the other hand, C. psittacus, A. clupeoides and Genyatremus luteus did not show any significant differences between seasons. Moreover, only the variables number of species, A. clupeoides (density and biomass) and Rhinosardinia amazonica (biomass) showed significant differences between creeks.

Cluster analysis demonstrated the existence of 2 distinct fish assemblage patterns in the creeks of the Furo do Meio. The first fish assemblage was represented principally by estuarine residents, marine seasonal migrants and marine juvenile migrants (Cathorops pleurops, Anchovia clupeoides, Pterengraulis atherinoides, Anableps anableps, Genyatremus luteus, Arius herzbergii, Cynoscion acoupa, Gobionellus oceanicus and Batrachoides surinamensis). The second fish assemblage was formed by marine juvenile migrants and marine adventitious visitors species (Lutjanus jocu, Caranx hippos, Strongylura timocu and Trichiurus lep-

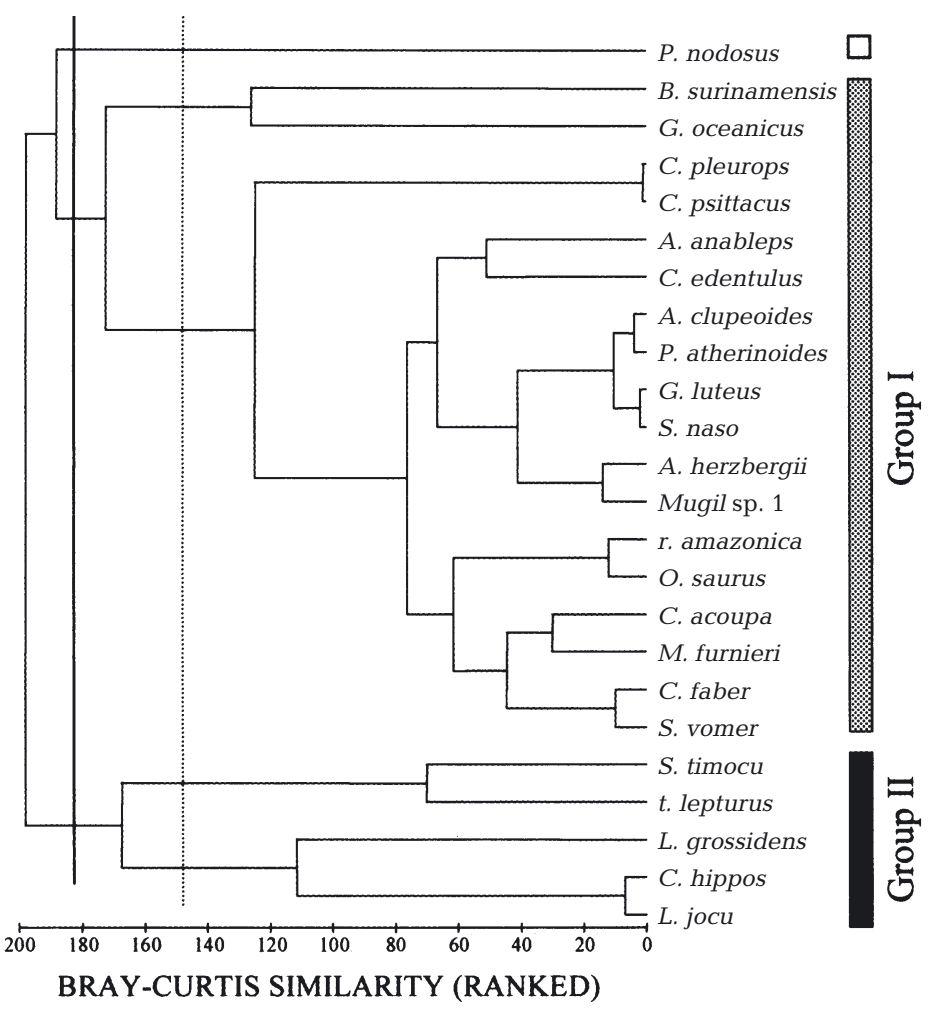

Fig. 6. Cluster dendrogram of contributions of the most important species to blocknet samples from the creeks of Furo do Meio. Samples clustered by group average of ranked BrayCurtis similarity index based on $\log (x+1)$-transformed biomass in 39 samples. Full specific names in Table 1

turus). The seasons influence the fish distribution in the creeks of Furo do Meio. For that reason 2 main groups were ordered in the cluster analysis: The first fish assemblage was represented by estuarine residents, marine seasonal migrants and marine juvenile migrants. The second fish assemblage consisted of marine juvenile migrants and marine adventitious visitor species. In addition, during the late rainy season the freshwater runoff increased, salinity decreased, and juvenile of Pseudauchnipterus nodosus (freshbrackishwater adventitious visitor) were found in the mangrove creeks during flood tide.

The ABC plots showed that in March and April, the most important species (Cathorops pleurops, Colomesus psittacus and Anchovia clupeoides) made up almost $80 \%$ of the total catch. However, the ANOVA results showed that the number of species did not differ significantly between seasons. This suggests that although the total fish biomass varied significantly between seasons, the fish species structure in the creeks of the Furo do Meio remained stable during the course of the year. However, during the peak rainy season (March and April), the lowest values of Hill's diversity index (N1) were observed. 
The significant increase in density and biomass of some species in the Furo do Meio creeks at the beginning of the rainy season suggests that these species were migrating into the mangrove tidal channels in the lower estuary because of an increase in freshwater runoff in the estuary. The tidal channels in the lower estuary may have served as refuge areas for those species that seek shelter when the estuary is strongly influenced by freshwater. The main tidal channels and their tidal creeks may have served as buffer areas for the intertidal fish community against a drastic reduction of salinity in the Caeté Estuary. This feature, which reflects the seasonal fish movement and migration among mangrove tidal channels, is explored in greater detail below. The same tendency was observed in the main channel of Caeté Estuary by Barletta-Bergan et al. (2002).

Table 2. Summary of results of ANOVA and Kruskal-Wallis tests on number of species and total (and component) density and biomass. Analysis performed on $\log (x+1)$-transformed data. Differences among creeks, season and species determined by Tukey post-hoc comparisons: ${ }^{*} \mathrm{p}<0,05 ;{ }^{* *} \mathrm{p}<0,01$; ns: not significant; Rs: rainy season; Ds: dry season; C1: Creek 1; C2: Creek 2; C3: Creek 3. Underlining indicates homogeneous groups

\begin{tabular}{|c|c|c|c|c|}
\hline \multirow[t]{2}{*}{ Parameters } & \multirow[b]{2}{*}{ Season } & \multicolumn{2}{|c|}{ - Source of variance } & \multirow[b]{2}{*}{ Interactions } \\
\hline & & Creek & Species & \\
\hline No. of species ${ }^{a}$ & ns & $* *$ & - & ns \\
\hline \multicolumn{5}{|l|}{ Density (ind. $\mathrm{m}^{-2}$ ) } \\
\hline Total $^{\mathrm{a}}$ & ns & ns & - & ns \\
\hline Main spp. ${ }^{b}$ & * & ns & ns & - \\
\hline Colomesus psittacus ${ }^{\mathrm{a}}$ & ns & ns & - & ns \\
\hline Anchovia clupeoides ${ }^{\mathrm{a}}$ & ns & 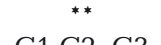 & - & ns \\
\hline Cathorops pleurops ${ }^{\mathrm{b}}$ & ${ }_{\mathrm{Rs}}^{*}>\mathrm{Ds}$ & $\frac{\mathrm{C} 1 \mathrm{C} 2}{\mathrm{~ns}} \underline{\mathrm{C} 3}$ & - & - \\
\hline Centengraulis edentulus ${ }^{\mathrm{b}}$ & ns & ns & - & - \\
\hline Genyatremus luteus $^{\mathrm{a}}$ & ns & ns & - & ns \\
\hline Pterengraulis atherinoides ${ }^{\mathrm{a}}$ & $\stackrel{* *}{* *}$ & ns & - & ns \\
\hline Rhinosardinia amazonica ${ }^{\mathrm{b}}$ & $\begin{array}{c}\text { Rs }>\text { Ds } \\
n s\end{array}$ & $\mathrm{~ns}$ & - & - \\
\hline Pseudauchnipterus nodosus ${ }^{\mathrm{b}}$ & $* *$ & ns & - & - \\
\hline Stellifer naso ${ }^{\mathrm{a}}$ & $\begin{array}{c}* * \\
\text { Rs }>\text { Ds }\end{array}$ & ns & - & ns \\
\hline \multicolumn{5}{|l|}{ Biomass $\left(\mathrm{g} \mathrm{m}^{-2}\right)$} \\
\hline Total $^{\mathrm{a}}$ & * & $\mathrm{ns}$ & - & ns \\
\hline Main spp. ${ }^{a}$ & $* *$ & ns & ns & ns \\
\hline Colomesus psittacus $^{\mathrm{a}}$ & ns & ns & - & ns \\
\hline Anchovia clupeoides ${ }^{\mathrm{a}}$ & ns & $\underline{\mathrm{C} 1 \mathrm{C}^{*}} \underline{\mathrm{C} 3}$ & - & - \\
\hline Cathorops pleurops ${ }^{\mathrm{a}}$ & $\begin{array}{c}* * \\
\mathrm{Rs}\end{array}$ & ns & - & ns \\
\hline Centengraulis edentulus ${ }^{\mathrm{b}}$ & ns & ns & - & - \\
\hline Genyatremus luteus $^{\mathrm{a}}$ & ns & ns & - & ns \\
\hline Pterengraulis atherinoides ${ }^{\mathrm{a}}$ & ${ }_{\text {Rs }}^{* *}>\mathrm{Ds}$ & ns & - & ns \\
\hline Rhinosardinia amazonica ${ }^{\mathrm{b}}$ & ns & * & - & - \\
\hline Pseudauchnipterus nodosus ${ }^{\mathrm{b}}$ & ** & ns & _- & _- \\
\hline Stellifer naso ${ }^{\mathrm{a}}$ & Rs $\stackrel{*}{>}$ Ds & ns & - & ns \\
\hline $\begin{array}{l}{ }^{\mathrm{a}} \text { ANOVA } \\
{ }^{\mathrm{b}} \text { Kruskall-Wallis test }\end{array}$ & & & & \\
\hline
\end{tabular}

\section{Seasonal movements of fish species in estuary}

Rain in the Caeté Estuary falls mainly from January to June, which is reflected by a high river discharge into Caeté Bay. During the peak of the rainy season (March and April) the Caeté River was a completely flushed system. Even in Caeté Bay (lower estuary), salt water of $>20$ psu was found only outside the estuary. At that time, a reduction in biomass occurred throughout the entire estuary, except in the Furo do Meio creeks (Barletta-Bergan et al. 2002, this study). However, the periods of high water discharge from the Caeté Estuary coincided with the peak period of dispersion of juvenile fishes from nearby coastal waters (Stellifer rastrifer, Cathorops spixii, Aspredo aspredo and Stellifer microps) (Barletta 1999) and from the Caeté River (Pimelodus blochii and Pseudauchnipterus nodosus) into the estuary and tidal creeks of the mangrove forest (Barletta-Bergan et al. 2002).

Males of Cathorops pleurops carrying eggs and juveniles with vitelline sacs in their mouths were caught in the Furo do Meio creeks from the end of December through April. This suggests that this species starts to spawn at the beginning of the rainy season. Juvenile Colomesus psittacus and Pterengraulis atherinoides were present during the same period. In addition, at the peak of the rainy season the total biomass and density of Cathorops pleurops, Colomesus psittacus and Pterengraulis atherinoides increased in the Furo do Meio creeks. These species were considered as residents in the mangrove forest creeks and main tidal channels. On the other hand, during the dry season at high tide, shoals of filter-feeding Cetengraulis edentulus and the carnivorous Strongylura timocu and Trichiurus lepturus inhabit the mangrove tidal creeks, where they can be considered as marine seasonal migrants. Juvenile Geniatremus luteus, Cynoscion acoupa and Micropogonias furnieri were caught throughout the entire sampling period. These are marine juvenile migrant species: marine coastal spawners that utilize the estuarine environment as a nursery in the post-larvae and juvenile stages. Young forms of Lutjanus jocu, Caranx spp., Tarpon 

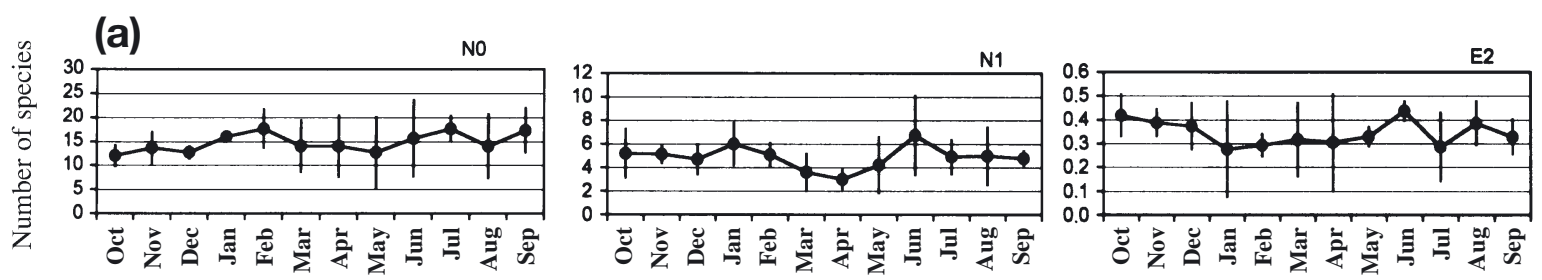

(b)
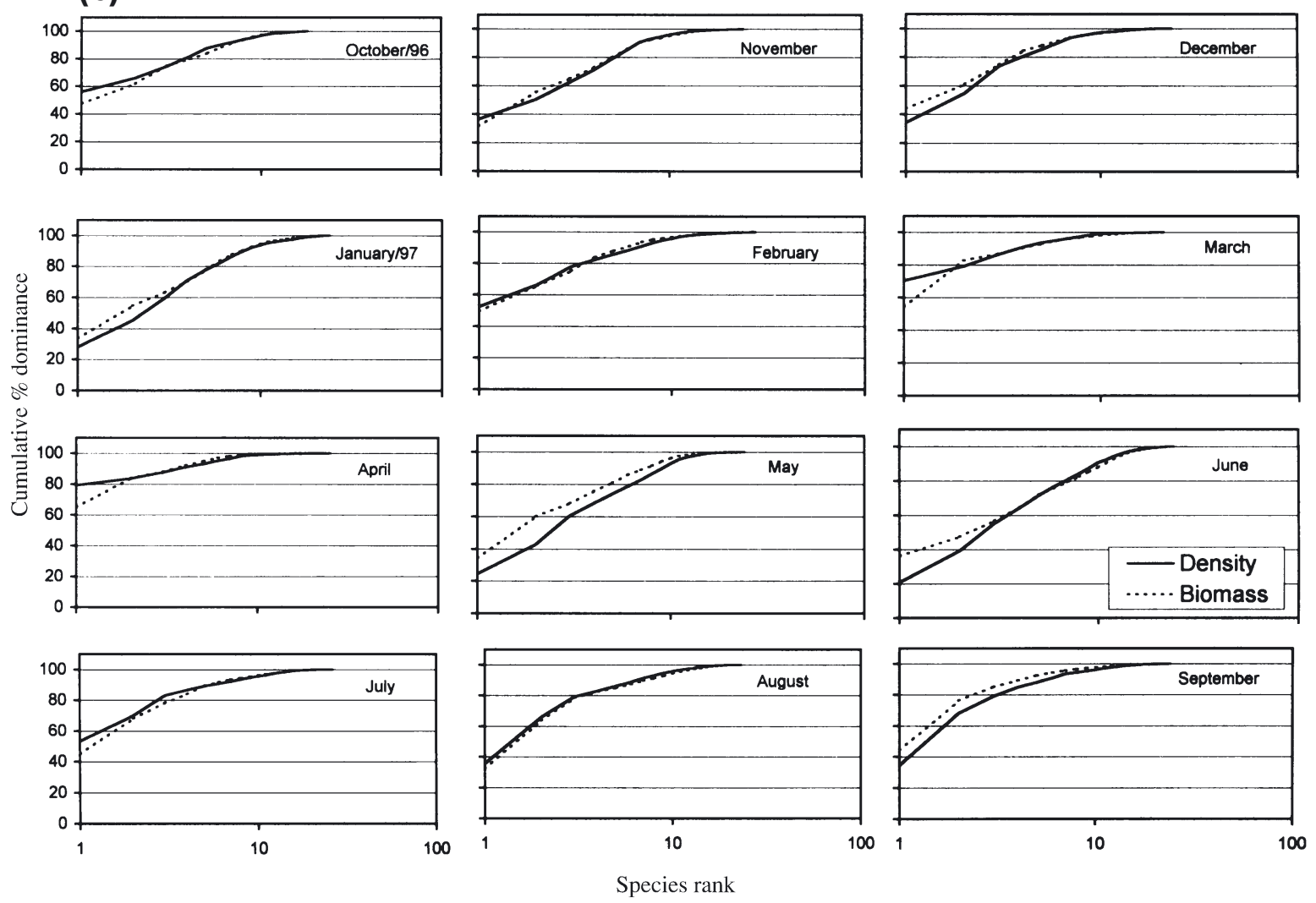

Fig. 7. (a) Annual mean (+SD) variation in number of species (N0), Hill's diversity index (N1), and equitability (E2); (b) abundance-biomass comparison $(\mathrm{ABC})$ plots ( $x$-axis logged) of species density (continuous line) and biomass (dotted line)

atlanticus and Scomberomorus maculatus (marine species) were caught in the mangrove creeks during the peak of the dry season (>30 psu). Juvenile Pseudauchnipterus nodosus (fresh-brackishwater species) were caught during the peak of the rainy season $(<10 \mathrm{psu})$.

Most of the species caught in the Furo do Meio were more abundant in the rainy season. On the other hand, most of the species caught in the main channel of the Caeté River were less abundant during the peak of the rainy season (Barletta 1999). This suggests that the fish assemblage in the main channel and the intertidal mangrove forest concentrates in coastal areas and in the mangrove tidal channel in the lower estuary during the rainy season. When we analyzed the movement pattern of both fish assemblages in the Caeté Estuary, it became clear that at the end of the rainy season both assemblages concentrated around the lower estuary and coastal areas. This pattern agrees with findings in Albatross Bay, north Australia (Blaber et al. 1989, 1990, Robertson \& Duke 1990), the Teacapán-Água Brava lagoon-estuarine system on the Mexican Pacific coast (Flores-Verdugo et al. 1990), and the Lagoa dos Patos lagoon-estuarine system in southern Brazil (Chao et al. 1985).

Seasonal changes in the catch rates of tropical and subtropical fish communities have also been reported in Madagascar (Laroche et al. 1997), south Florida (Thayer et al. 1987), Guyana (Lowe-McConnell 1987), northern Brazil (Batista \& Rêgo 1996) and SE Brazil (Giannini 1989). These changes have been ascribed mainly to reproductive patterns and increased recruitment. Blaber et al. (1990) suggested that this phenomenon of fish concentrating around estuaries, together with the probability that during the rainy season non- 
estuarine species move to the lower estuary, may explain the correlation between fish abundance and rainfall. The results of the present study support these theories. We add that the seasonal changes in estuarine fish assemblages may be determined by a combination of temporal fluctuations in the fish assemblage induced by rainfall, reproduction and recruitment of resident estuarine species, and recruitment of marine or freshwater species.

In the Caeté Estuary, as in other tropical and subtropical estuaries, rainfall strongly (although indirectly) influences the seasonal movements of fish species. Together these movements result in a succession of fish species composition in these mangrove creeks. When conditions are propitious, many marine and/or freshwater juvenile fishes, together with the resident species, enter with every flood tide to exploit this environment. Therefore it can be concluded that all fish species caught in this study are, to different degrees, estuary-dependent.

\section{Comparisons of intertidal fish fauna in Furo do Meio with those in other mangrove creeks}

Principally due to variations in sampling methods and sampling effort, also because of differences in geomorphology and tidal range of estuaries, care is needed in comparing mangrove ecosystems regarding density, biomass, and species composition. Therefore, we have used only those studies that utilized similar sampling methods in the mangrove habitats.

Studies using block nets, in intertidal mangrove forests in Moreton Bay in subtropical eastern Australia
(Morton 1990), Embley Estuary in tropical Australia (Blaber et al. 1989), intertidal mangrove areas in the Solomon Islands in the Pacific Ocean (Blaber \& Milton 1990) and prop-root habitats in the mangrove forest in Whitewater Bay and Coot Bay in south Florida, USA (Thayer et al. 1987) recorded varying numbers of species, density, and biomass (Table 3). The density and biomass values for block net samples recorded in mangrove creeks in the present study were lower than those for mangrove forest creek habitats in south Florida, Australia and the Solomon Islands. Catches made with a seine net in the mangrove tidal canal in the Caeté Estuary (Barletta 1999), however, showed values comparable to those reported by Morton (1990), although the biomass values were higher than Morton's (Table 3), whose results were based on different sampling periods, and were taken in different regions with different tidal amplitudes. However, the biomass values in this study were comparable to those reported from Coot Bay, south Florida (Thayer et al. 1987). Theses differences may reflect different sampling techniques, as most studies have used different methods (e.g. small sampling area and fish poison). The possibility that the larger mobile species were not sampled adequately in this study is rejected, because in this region (tidal range up to $4 \mathrm{~m}$ ) at low tide these intertidal mangrove forest creeks are not influenced by tidal water, meaning that all 49 fish species sampled in this study (all of which show intertidal movement behavior) moved out of the tidal mangrove creeks with the ebb tide. The studies in south Florida (Thayer et al. 1987), northern and eastern Australia (Blaber et al. 1989, Morton 1990), and the Solomon Islands (Blaber \& Milton 1990), all recorded ray and shark species in

Table 3. Sampling gear, number of species, total density and total biomass of fishes captured in different mangrove intertidal habitats in Caeté Estuary and Tibiri Estuary (north Brazil), Everglades (south Florida, USA), Embley and Moreton Bay (Australia) and Solomon Islands (Pacific Ocean). Species number in Everglades is sum of all species captured in Whitewater and Coot Bays.

$$
- \text { : no data }
$$

\begin{tabular}{|c|c|c|c|c|c|}
\hline Location and habitat & Sampling gear & No. spp. & $\begin{array}{c}\text { Density } \\
\left(\text { ind. } \mathrm{m}^{-2} \text { ) }\right.\end{array}$ & $\begin{array}{c}\text { Biomass } \\
\left(\mathrm{g} \mathrm{m}^{-2}\right)\end{array}$ & Source \\
\hline \multicolumn{6}{|l|}{ North Brazil } \\
\hline Caeté Estuary, mangrove tidal creeks & Block net & 49 & 0.11 & 2.1 & This study \\
\hline Tibiri Estuary, mangrove tidal creeks & Block net & 34 & - & - & Batista \& Rêgo (1996) \\
\hline Caeté Estuary, mangrove tidal canal & Seine net & 13 & 0.82 & 9.85 & Barletta (1999) \\
\hline Everglades, USA & & 64 & & & \\
\hline Whitewater Bay, prop root habitat & Block net & & 4.7 & 10.8 & Thayer et al. (1987) \\
\hline Coot Bay, prop root habitat & Block net & & 2.6 & 5.3 & Thayer et al. (1987) \\
\hline \multicolumn{6}{|l|}{ Australia } \\
\hline Embley Estuary, mangrove creeks & Block net and rotenone & 66 & - & 8.2 & Blaber et al. (1989) \\
\hline Moreton Bay, mangrove forest & Block net & 41 & 0.27 & 25.3 & Morton (1990) \\
\hline Moreton Bay, adjacent habitats to mangrove & Seine net & 30 & 0.15 & 2.9 & Morton (1990) \\
\hline \multicolumn{6}{|l|}{ Pacific Ocean } \\
\hline Solomon Islands, mangrove intertidal areas & Block net and rotenone & 85 & - & 11.6 & Blaber \& Milton (1990) \\
\hline
\end{tabular}


their catches. The fact that we did not catch species of Chondrichthyes may account for the low density and biomass in the mangrove forest tidal creeks in the Furo do Meio. Along the northern Brazilian coast ( $>20 \mathrm{~m}$ depth), specimens of Dasyatis spp., Aetobatus narinari, Carcharinus spp., and Sphyrna spp. have been caught by longlines and gill nets (Barletta et al. 1998). However, these species did not appear in our samples. Batista \& Rêgo (1996) carried out similar studies with a similar sampling method in the tidal creeks of the Tibiri Estuary (NE Brazil). The fish composition and seasonal behavior were similar to those found in this study, and Batista \& Rêgo (1996) likewise caught no species of Chondrichthyes. Unfortunately, Batista \& Rêgo (1996) did not express their results as fish species density (ind. $\mathrm{m}^{-2}$ ) or biomass $\left(\mathrm{g} \mathrm{m}^{-2}\right)$. They showed the seasonal variations in the fish fauna as ranges of ecological index values (Shannon-Wiener $H^{\prime}$, range of means $=1.33$ to 1.74 ). The fish composition in the intertidal mangrove creeks of the Tibiri Estuary was apparently similar to that found in this study (Hill's N1 index range of means of 3.02 to 7.0 corresponds to 1.10 to 1.95 for $H^{\prime}$ values). However, although both studies showed differences in diversity between seasons, this was not so for equitability. According to Vieira \& Musik (1994), in tropical estuaries interspecific relationships develop that result in more productive utilization of this environment. This suggests that the utilization of areas protected from predators and rich in food by the resident and by the estuary-dependent young-of-theyear of many marine and freshwater fishes throughout the year is expressed by the stabilization of equitability (Batista \& Rêgo 1996, this study).

Acknowledgements. This study resulted from the cooperation between the Centre for Tropical Marine Ecology (ZMT), Bremen, Germany, and the Universidade Federal do Pará (UFPA) and the Museu Paraense Emílio Goeldi (MPEG), both Belém, Brazil, under the Governmental Agreement on Cooperation in the Field of Scientific Research and Technological Development between Germany and Brazil that is financed by the German Ministry for Education, Science, Research and Technology (BMBF, project number 03F0154A, Mangrove Management and Dynamics, MADAM), and the Conselho Nacional de Desenvolvimento Científico e Tecnológico (CNPq), of the Ministry for Science and Technology of Brazil. The first author was supported by a CNPq grant (No. 290057/95-7). We thank Dr. Robin Gibson, Dr. Steve Blaber and 4 anonymous reviewers for helpful comments on earlier versions of this manuscript.

\section{LITERATURE CITED}

Barletta M (1999) Seasonal changes of density, biomass and species composition of fishes in different habitats of the Caeté estuary (north Brazilian coast-east Amazon). PhD thesis, University of Bremen

Barletta M, Barletta-Bergan A, Saint-Paul U (1998) Descrip- tion of the fishery structure in the mangrove dominated region of Bragança (State of Pará-north Brazil). Ekotropica $4: 41-53$

Barletta M, Saint-Paul U, Barletta-Bergan A, Ekau W, Schories D (2000) Spatial and temporal distribution of Myrophis punctatus (Ophichtidae) and associated fish fauna, in a north Brazilian intertidal mangrove forest. Hydrobiologia 426:65-74

Barletta-Bergan A, Barletta M, Saint-Paul U (2002) Structure and seasonal dynamics of larval fish in the Caeté River in north Brazil. Estuar Coast Shelf Sci 54:193-206, available online at www.idea/library.com

Batista VS, Rêgo FN (1996) Análise de associações de peixes, em igarapés do estuário do Rio Tibiri, Maranhão. Rev Bras Biol 56:163-176

Blaber SJM (2000) Tropical estuarine fishes: ecology, exploitation \& conservation. Blackwell, Oxford

Blaber SJM, Blaber TG (1980) Factors affecting the distribution of juvenile estuarine and inshore fish. J Fish Biol 17: 143-162

Blaber SJM, Milton DA (1990) Species composition, community structure and zoogeography of fishes of mangrove estuaries in the Solomon Islands. Mar Biol 105:259-268

Blaber SJM, Brewer DT, Salini JP (1989) Species composition and biomass of fishes in different habitats of a tropical northern Australia estuary: their occurrence in the adjoining sea and estuarine dependence. Estuar Coast Shelf Sci 29:509-531

Blaber SJM, Brewer DT, Salini JP, Kerr J (1990) Biomass, catch rates and abundances of demersal fishes, particularly predators of prawns, in a tropical bay in the Gulf of Carpentaria, Australia. Mar Biol 107:397-408

Chao LN, Pereira LE, Vieira JP (1985) Estuarine fish community of the Dos Patos Lagoon, Brazil: a baseline study. In: Yáñez-Arancibia (ed) Fish community ecology in estuaries and coastal lagoons: towards an ecosystem integration. DR (R) Universidade Autónoma de México Press, Mexico City, p 429-450

Clarke KR, Warwick RM (1994) Change in marine communities: an approach to statistical analysis and interpretation. Natural Environment Research Council, Plymouth

Day RW, Quinn GP (1989) Comparisons of treatments after analysis of variance in ecology. Ecol Monogr 59:433-463

Flores-Verdugo F, González-Farías F, Ramíres-Flores O, Amezcua-Linares F, Yáñez-Arancibia A, Alvarez-Rubio M, Day JW (1990) Mangrove ecology, aquatic primary productivity, and fish community dynamics in the Teacapán-Agua Brava lagoon-estuarine system (Mexican Pacific). Estuaries 13:219-230

Gauch HG (1982) Multivariate analysis in community structure. Cambridge University Press, Cambridge

Giannini R (1989) Distribuição temporal e espacial e aspectos bioecológicos da família Sciaenidae na baía de Santos, SP, Brasil. MSc thesia, São Paulo

Gibson RN (1996) Intertidal teleost: life in a fluctuating environment. In: Pitcher TJ (ed) Behaviour of teleost fishes, 2nd edn. Chapman \& Hall, London, p 513-533

Griffin RK (1985) The importance of mangrove/coastal wetlands to three commercial fisheries in the Northern Territory; particularly for barramundi (Lates calcarifer). In: Bardsley KN, Davie JDS, Woodroffe CD (eds) Coasts and tidal wetlands of the Australian monsoon region. Australian National University, Sydney, p 277-283

Kjerfvue B (1990) Manual for investigation of hydrological process in mangrove ecosystems: research and its application to the management of the mangroves of Asia and the Pacific. Ref. RAS/86/120. UNESCO, Paris 
Laroche J, Baran E, Rasoanandrasana NB (1997) Temporal patterns in a fish assemblage of a semiarid mangrove zone in Madagascar. J Fish Biol 51:3-20

Lenaton RC, Potter IC (1987) Contribution of estuaries to commercial fisheries in temperate western Australia and concept of estuarine dependence. Estuaries 10: 367-382

Lowe-McConnell RH (1987) Ecological studies in tropical fish communities. Cambridge University Press, Cambridge

Ludwig JA, Reynolds JF (1988) Statistical ecology: a primer of methods and computing. John Wiley \& Sons, New York

Mathieson S, Cattrijsse A, Costa MJ, Drake P, Elliot M, Gardner J, Marchand J (2000) Fish assemblages of European tidal marshes: a comparison based on species, families and functional guilds. Mar Ecol Prog Ser 204:225-242

Morton RM (1990) Community structure, density and standing crop of fishes in a subtropical Australian mangrove area. Mar Biol 105:385-394

Robertson AI, Blaber SJM (1992) Plankton, epibenthos and fish communities. In: Robertson AI, Alongi DM (eds)

Editorial responsibility: Otto Kinne (Editor), Oldendorf/Luhe, Germany
Tropical mangrove ecosystems. American Geophysical Union, Washington, DC, p 173-224

Robertson AI, Duke NC (1990) Mangroves as nursery sites: comparisons of the abundances and species composition of the fish and crustaceans in mangroves and other nearshore habitats in tropical Australia. Mar Biol 96: 193-205

Romesburg HC (1984) Cluster analysis for researchers. Lifetime Learning, Belmont, CA

Thayer GW, Colby DR, Hettler WF (1987) Utilization of the red mangrove prop root habitat by fishes in South Florida. Mar Ecol Prog Ser 35:25-38

Underwood AJ (1981) Techniques of analysis of variance in experimental marine biology and ecology. Oceanogr Mar Biol Annu Rev 19:513-605

Vieira JP, Musick JA (1994) Fish faunal composition in warmtemperate and tropical estuaries of the western Atlantic. Atlântica 16:31-53

Zar JH (1996) Biostatistical analysis, 3rd edn. Prentice-Hall, Upper Saddle River, NJ

Submitted: July 30, 2002; Accepted: January 30, 2003

Proofs received from author(s): June 20, 2003 